\title{
PEMANFAATAN ENERGI TERBARUKAN OF GRID di DAERAH TERPENCIL INDONESIA
}

\author{
Gunawan Sihombing ${ }^{1}$, Suwarno ${ }^{2}$ \\ 12 Universitas Muhammadiyah Sumatera Utara \\ gunawansihombing6939@gmail.com \\ Suwarno@umsu.ac.id
}

\begin{abstract}
ABSTRAK
Daerah yang terisolasi dari jaringan listrik memerlukan pasokan energi listrik untuk meningkatkan ekonomi, sosial dan lingkungan. sistem RES of grid menjadi solusi yang layak baik secara teknis dan ekonomi.Dalam menyelesaikan masalah energi di daerah terpencil Indonesia. Tujuan dari Makalah ini adalah untuk meninjau kebijakan energi baru dan terbarukan of grid Indonesia dengan berfokus pada daerah tertinggal di Indonesia Bagian Timur Makalah ini mengidentifikasikan peluang investasi untuk pengembangan energi baru dan terbarukan.Pengalaman internasional dengan promosi energi baru terbarukan seperti Alaska dan Kanada.Makalah ini menguji kelayakan alternatif terbaik mekanisme praktik untuk mendukung energi terbarukan di luar jaringan Indonesia.
\end{abstract}

Kata Kunci: alternatif, of grid, terbarukan

\begin{abstract}
Areas that are isolated from the electricity grid need a supply of electrical energy to improve the economy, social and environment. The RES of grid system is a feasible solution both technically and economically. In solving energy problems in remote areas of Indonesia. The purpose of this paper is to review Indonesia's of-grid new and renewable energy policies with a focus on underdeveloped regions in Eastern Indonesia. This paper identifies investment opportunities for new and renewable energy development. International experience with the promotion of new and renewable energy such as Alaska and Canada feasibility of alternative best practice mechanisms to support renewable energy outside the Indonesian grid.
\end{abstract}

Keyword: alternative of grid, renewable

\section{Pendahuluan}

Daerah yang terisolasi dari jaringan listrik memerlukan pasokan energi listrik untuk meningkatkan ekonomi sosial dan juga lingkungan.Sistem RES of grid menjadi solusi yang layak baik secara teknis dan ekonomi. Dalam Menyelesaikan masalah energi di daerah terpencil [1] memerlukan kebijakan khusus atau dukungan peraturan yang berbeda dari peraturan yang ada atau mekanisme yang baru untuk mempromosikan jaringan RES yang terhubung dengan jaringan terpusat [2] untuk mengatasi RES of grid maka perlu pendekatan khusus untuk mengatasi masalah teknis masalah keuangan dan peraturan tertentu yang berkaitan dengan penggunaan RES of grid [3] [4] [5] dukungan penggunaan RES of grid harus menyesuaikan antara kondisi nasional dan juga kondisi di daerah tertentu untuk dapat mempertimbangkan antara karakteristik dengan kebijakan energi 
nasional [6] [7] [8]. Sebagai contoh saat ini sangat besar perhatian dunia tentang promosi of grid di Kanada [9][10][11] India [12] [13] Neval [14] dengan sedikitnya minat di daerah asia tenggara khususnya di Indonesia. Maka dengan ini artikel ini bertujuan untuk berpartisipasi pada literatur kebijakan of grid dan peraturan yang ada di Indonesia khususnya peraturan daerah untuk dapat mempromosikan pengembangan investasi of grid di daerah terpencil khususnya di daerah Indonesia Bagian Timur yang belum tersambung jaringan listrik. Indonesia Bagian Timur paling menarik untuk mengkaji tantangan dan peluang yang berkaitan dengan of grid. Selain listrik yang terintegrasi Indonesia dapat memanfaatkan of grid khususnya di daerah kepulauan dan juga pemukiman terpencil. Sistem terisolasi dan pemukiman terpencil ini bergantung pada sumber energi diesel.

Dengan ketergantungan pada energi diesel maka perlu promosi dan sosialisasi tentang pemanfaatan of grid di daerah tersebut. Sekitar $50 \%$ pembangkit listrik Indonesia berasal dari apa yang disebut dengan bahan bakar diesel. Pembangkit listrik dari solar sangat mahal karena bahan bakar harus dikirim melalui jarak yang jauh dan kurang efektif. Pada proses produksi tenaga listrik di Indonesia Bagian Timur cuaca dan Infrastruktur menjadi kendala menyulitkan akses ke daerah terpencil. Dengan banyaknya kendala yang dihadapi dalam memasok energi listrik di daerah terpencil masalah seperti ini sulit dikelola karena berkaitan dengan perubahan iklim dan berdampak pada ketersedian pasokan listrik di daerah. Produksi diesel pada pembangkit listrik adalah pembangkit yang intensif dengan karbon dan sangat berkonstribusi pada perubahan iklim sebagai contoh di daerah artik Rusia dampak karbon hitam dari diesel mempercepat pemanasan global meningkatkan tingkat pencairan dan meningkatkan pemanasan tambahan [15].

Untuk memasok energi yang ramah lingkungan dan dengan harga yang lebih terjangkau maka perlu beralih dari energi diesel ke angin dan energi hibrid lainnya [1-5]. Sistem energi hibrid of grid dapat mengurangi energi diesel yang berdampak pada lingkungan. RES bertujuan untuk menghindari ekstensi biaya jaringan yang tinggi [14][16][17]. Penggunaan of grid dapat mengurangi saluran transmisi yang panjang dan juga mengurangi risiko terhadap keamanan energi sebagai contoh gangguan transmisi.

Peraturan Pemerintah melalui surat Kementerian Energi dan Sumber Daya Mineral berupaya untuk pencapaian Sustainable Development Goal's (SDG's) tentang permen no 7 yaitu masyarakat memiliki akses energi yang terjangkau handal 
dan berkelanjutan modern, melalui kebijakan energi berkeadilan sebagai upaya mencapai kebijakan energi nasional. Kementeria ESDM menerapkan kebijakan bahwa energi yang berkelanjutan dan terjangkau bagi seluruh rakyat Indonesia dan juga pemerintah berkomitmen dalam memeperluas penggunaan dan pemanfaatan energi terbarukan melalui kebijakan dan peraturan yang berbasis produktivitas dan inovasi.

Dengan banyaknya permasalahan di atas maka penelitian ini bertujuan untuk mengatasi masalah energi listrik di daerah Indonesia Bagian Timur dengan memanfaatkan energi terbarukan yang ramah lingkungan seperti energi yang berasal dari sumber-sumber alamiah seperti sinar matahari, angin, hujan, geothermal dan biomassa dengan berfokus pada RES of grid sebagai pemasok dan penyimpan energi listrik demi tercapai percepatan pembangunan energi nasional.

Kebijakan strategis yang diterapkan Pemerintah diantaranya:

Mendorong pemanfaatan PLTS atap sesuai amanat Peraturan Menteri ESDM Nomor 49 Tahun 2018 tentang Penggunaan Sistem Pembangkit Listrik Tenaga Surya Atap oleh Konsumen PLN, Percepatan pembangunan PLTSa di 12 kota terpilih, sesuai amanat pada Peraturan Presiden Nomor 35 Tahun 2018 tentang Percepatan program Pembangunan PLTSa [18].

\section{Metode Analisis Regulasi Dari Dukungan} yang Tersedia Tentang RES of Grid

Tantangan terbesar yang dihadapi demi terealisasinyta energi hibrid angin dan solar adalah masalah keuangan dan ekonomi di daerah terpencil. Sebagai contoh sebanyak 222 daerah di Kalimantan Timur yang belum teraliri listrik diakibatkan oleh infrastruktur yang jauh dan daerah yang ketinggalan zaman. Prospek ekonomi seperti ini dapat memperburuk risiko terealisasinya of grid $\mathrm{di}$ daerah. Tujuan dari artikel ini berkonstribusi pada RES metode kuantitatif secara tidak langsung terlibat dengan teknik keuangan ekonomi dan juga aspek ekonomi RES of grid.

Maka dengan demikian artikel ini menggunakan metode kualitatif karena dengan menggunakan metode ini bagaimana hukum dapat berkonstribusi untuk mengatasi kendala yang dihadapi investasi RES of grid dan juga analisis RES of grid sangat penting. Tidak ada intermalisasi dan ekstemalitas pasokan energi pada pengembangan RES pasokan energi bergantung pada kerangka hukum yang di tetapkan oleh daerah tertentu sebagai alternatif dan juga penggunaan sumber energi tradisional. Peranan metodologi penelitian hukum sangat penting untuk merancang atau mengidentifikasi solusi dari masalah yang ada 
tentang penerapan RES [19][20]. Dengan pentingnya sistem hukum nasional investasi RES dapat beroperasi maka perlu aturan hukum yang mengatur promosi RES fokus Makalah ini adalah pada peraturan RES di Indonesia dengan demikian hukum RES of grid tidak dapat memeriksa isolasi dari pada keuangan teknis dari teknologi belajar dari sanalah pengembangan of grid di daerah terpencil demi menghasilkan energi yang bermanfaat bagi daerah tertentu dan juga bermanfaat bagi daerah tersebut.

Analisa yang ada pada topik ini oleh para ahli kebijakan energi ekonomi dan juga kebijakan teknik dan juga analisis hukum di pusat belajar membangun pekerjaan yang sudah ada untuk menghasilkan dan mengusulkan mekanisme regulasi yang disesuaikan dengan ekonomi dan juga sosial dan karakteristik investasi of grid.

\subsection{Peraturan Listrik di Daerah Terpencil Indonesia}

Untuk memenuhi ketenaga listrikan nasional khususnya daerah terpencil pemerintah mengeluarkan peraturan melalui Kementerian SDM Nomor 38 tahun 2016 tentang percepatan elektrifikasi di daerah pedesaan yang belum berkembang baik di daerah terpencil perbatasan pulau terpencil yang berpenduduk atau yang memiliki penduduk melalui penyedia tenaga listrik dalam skala kecil.Melalui
Peraturan Menteri ESDM BUMN dan Swasta juga koperasi dapat mengelola dan membuat usaha tenaga listrik di daerah yang belum teraliri listrik.Peraturan yang di keluarkan oleh Kementerian ESDM memberikan kemudahan bagi pemerintah daerah untuk berkewenangan dalam memberikan kesempatan kepada penyelenggara usaha atau penyedia tenaga listrik terintegrasi untuk untuk menyediakan energi listrik dalam skala kecil.

Pemanfaatan energi baru dan terbarukan sebagai sumber energi listrik di daerah pedesaaan dapat mempercepat elektrifikasi di daerah tersebut. Berdasarkan peraturan ini apabila badan usaha tidak ada yang berminat mengikuti seleksi penyelengara usaha penyedia tenaga listrik maka Pemerintah Daerah atau Gubernur dapat menunjuk BUMD untuk menyelenggarakan UPTL dalam skala kecil. Seperti yang tertuang dalam peraturan ESDM No 12 Tahun 2017 tentang pelaksanaan pembelian tenaga listrik dari pembangkit listrik dan memanfaatkan energi baru dan terbarukan yang efisien dan variatif dan tergantung pada cuaca di daerah. Sistem Pelelangan energi seperti energi sinar matahari dan angin dilakukan Oleh PLN (Persero) berdasarkan kuota kapasitas yang tersedia.sedangkan harga pembelian tenaga listrrik melalui mekanisme pemilihan langsung baik dari tenaga air Pembangkit Listrik Tenaga Biomassa (PLTBm), Pembangkit Listrik 
Tenaga Biogas (PLTBg), Pembangkit Listrik Tenaga Sampah (PLTSa),Pembangkit Listrik Tenaga Panas Bumi (PLTP).

Harga Biaya Pokok Penyediaan Pembangkitan Dalam hal BPP nasional dibawah biaya BPP daerah harga pembelian tenaga listrik paling tinggi sebesar $85 \%$ dari BPP setempat. PLTSa dan PLTP paling tinggi sebesar BPP yang di tetapkan oleh daerah. BPP nasional dan BPP setempat memiliki harga yang sama tentang pembelian energi atau khusus PLTsa atau PLTP ditetapkan kesepakatan oleh PLN (Persero). PLN wajib terbuka tentang ketenaga listrikan suatu daerah yang siap menerima pembangkit tenaga listrik yang memanfaatkan sumber dari energi terbarukan.

Mempublikasikan pokok-pokok PJBL yang disusun oleh PLN (persero) mengacu pada perundang-undangan yang berlaku dengan ketentuan peralihan

- Badan usaha yang mendapat kepercayaan atau pemenang kuota kapasitas Pembangkit Listrik Tenaga Biomassa (PLTBm),Pembangkit Listrik Tenaga Biogas (PLTBg), Pembangkit Listrik Tenaga Sampah (PLTSa), Pembangkit Listrik Tenaga Panas Bumi (PLTP). Dengan kata lain pemenang lelang WKP panas bumi yang telah menanda tangani PJBL dan pembelian harga sesuai dengan PJBL yang ditanda tangani.

Terhadap Badan usaha yang telah mendapatkan penetapan sebagai pengelola tenaga air,atau penetapan sebagai pengembang PLTBm, PLTBg, atau PLTSa dan belum menandatangani PJBL. Proses pelaksanaan pembeliannya sesuai dengan aturan yang dibuat sebelumnya sepanjang tidak bertentangan sedangkan mengenai harga mengacu pada ketentuan Permen ini.Terhadap pemenang lelang WKP panas bumi baik badan usaha dan lainnya yang belum menandatangani PJBL serta BUMN yang mendapat penugasan tentang pengusahaan panas bumi,proses pelaksanaan dan harga tenaga listrik sesuai dengan ketentuan sebelumnya [22].

\subsection{Strategi Indonesia ke Depan}

Pemerintah Indonesia menyebut bahwa Indonesia berkomitmen utuk mencapai target penggunaan EBT sebesar $23 \%$ pada baruan energi nasional di tahun 2025 sebagai salah satu pemenuhan target kebijakan energi nasional dan paris egrimen dengan demikian harapan Indonesia ke depan bisa menuju net zero emission dapat tercapai.

Pembangunan ekonomi menjadi prioritas pemerintah Indonesia dalam hal ini jaminan keamanan keandalan pasokan listrik dan 
sumber kehidupan ekonomi sangat penting. Energi terbarukan menjadi bagian dari kebijakan kelistrikan Indonesia khususnya di daerah terpencil. Kebijakan Pemerintah Indonesia menganggap bahwa energi baru dan terbarukan dapat mengatasi mahalnya pasokan listrik di daerah terpencil.

Menurut Pemerintah kebijakan ini akan memberikan pengaruh positif pada daerah untuk menciptakan lapangan kerja di daerah. Inplementasi of-grid investasi menghadapi tantangan teknik Keuangan ekonomi yang sangat besar. Biaya proyek penggunaan RES di daerah yang mudah diakses lebih rendah dibandingkan biaya RES di daerah terpencil [23]. Tantangan teknis untuk daerah terpencil adalah pengelolaan variabilitas angin dan energi surya yang berkaitan dengan produksi minimum keluaran berfungsi untuk memastikan fungsi diesel yang efisien pada instalasi generasi [24].

Dengan menggunakan penyimpanan dapat memaksimalakan efisiensi sistem dan menjaga stabilitas grid terhadap penetrasi angin kasus ini dapat menyebabkan pasokan energi yang tinggi $[1,3]$. Hubungan sistem terisolasi dan pengaturan jarak Jauh mejadi solusi pada jaringan terpusat untuk mewakili risiko pada saat terjadi jaringan mati.

\subsection{Skema Pemerintah untuk Memanfaatkan}

\section{Energi Terbarukan di Daerah Terpencil}

Pemerintah mendukung penggunaan RES of grid untuk produksi listrik di daerah khususnya daerah tertinggal.Tingkat nasional dukungan diberikan melalui perjanjian yang diatur oleh Permen ESDM No.12 Tahun 2017 tentang Pemanfaatan sumber energi terbarukan sebagai penyediaan tenaga listrik. Maksud dan ruang lingkup Permen terkait jenis pembangkit tenaga listrik yang memanfaatkan sumber energi terbarukan yaitu PLTS Fotovoltaik,Pembangkit Listrik Tenaga Bayu (PLTB), Pembangkit Listrik Tenaga Air (PLTA),Pembangkit Listrik Tenaga Biomassa (PLTBm),Pembangkit Listrik Tenaga Biogas (PLTBg),Pembangkit Listrik Tenaga Sampah (PLTSa),dan Pembangkit Listrik Tenaga Panas Bumi (PLTP)[21]. Promosi RES di daerah terpencil perlu memperhitungkan keuangan tertentu maka diperlukan pemeriksaan mekanisme supaya berhasil dan dapat diterapkan di daerah terpencil.Instalasi of grid berpartisipasi dalam ritel Indonesia dan memberikan dukungan demi kemajuan listrik nasional dengan fasilitas dibawah $25 \mathrm{Mw}$. Menurut undang-undang listrik nasional Pemerintah daerah membuat kebijakan terhadap tarif listrik untuk RES yang dapat di beli oleh Perusahaan Listrik Nasional (PLN) [25]. Keputusan no 12 tahun 12 tentang pemanfaatan sumber energi terbarukan untuk daerah terpencil memberikan jawabanterhadap 
peraturan yang menghambat investasi RES of grid di daerah terpencil atau daerah yang belum teraliri listrik. Proyek-proyek RES di luar jaringan memberikan perjanjian tentang tarif pembelian daya untuk bisa membayar utang proyek tertentu.

Menurut undang-undang listrik nasional menetapkan bahwa penyediaan tenaga listrik dikuasai oleh negara dan penyelenggaraannya dilakukan oleh Pemerintah Pusat pemerintah daerah yang berlandaskan peraturan otonomi daerah(2). Untuk penyelenggaraan penyediaan tenaga listrik sebagaimana di maksud pada ayat(1),sesuai dengan kewenangan Pemerintah Pusat dan Pemerintah Daerah menetapkan kebijakan,pengaturan,pengawasan,dan melaksanakan usaha penyediaan tenaga listrik. Penetapan izin jual beli tenaga listrik lintas negara,dan penetapan izin usaha penyediaan tenaga listrik untuk badan usaha dilakukan oleh Badan Usaha Milik Negara (BUMN). Persetujuan penjualan tenaga listrik dari pemegang izin operasional ditetapkan Oleh pemerintah dan penetapan usaha ini dilakukan oleh BUMN. Penetapan izin ini untuk pemanfaatan jaringan tenaga listrik kepentingan telekomunikasi, multimedia, dan informatika [24]. Regulasi pasar listrik nasional yang terletak di jakarta harus menilai apakah RES yang di buat memenuhi semua persyaratan dan kualifikasi yang ditentukan oleh Pemerintah Pusat dan juga Pemerintah daerah.

Pada pemukiman terpencil dan juga jarak jauh di daerah Indonesia Bagian Timur instalasi di daerah lokasi RES of grid, penilaian terhadap RES dilakukan setelah semua prosedur dilakukan dengan baik.Proses selanjutnya di lakukan dari sudut pandang investor karena tarif di tentukan Setelah kualifikasi (penilaian dari pihak pemerintah) Pemerintah Daerah Memiliki wewenang mengatur tarif yang tepat terhadap bisnis yang buat oleh para investor. Dari pengalaman internasional tentang kehandalan intitusional dan stabilitas peraturan adalah menjadi kunci demi mengamankan partisispasi investor dalam mengembangkan proyek energi terbarukan of grid.

\section{Hasil Penghalang of Grid dan Investasi}

Pemerintah mengakui bahwa pemanfaatan energi terbarukan of grid bagi ekonomi sosial dan juga lingkungan yang beralih dari diesel ke RES dapat menjadi solusi bagi ketersediaan energi listrik di daerah terpencil Indonesia Bagian Timur. Pada 25 November 2016 Pemerintah menerbitkan Peraturan Menteri ESDM Nomor 38 tahun 2016 tentang Percepatan Elektrifikasi di Perdesaan belum Berkembang, Terpencil, Perbatasan dan Pulau Kecil berpenduduk melalui pelaksanaan usaha penyediaan tenaga listrik skala kecil. 
Permen ini memberikan kemudahan bagi Pemerintah Daerah untuk berkewenangan dalam memberikan kesempatan kepada badan usaha sebagai penyelenggara usaha penyediaan tenaga listrik terintegrasi untuk skala kecil. Selain itu, program percepatan elektrifikasi di pedesaan ini memanfaatkan penggunaan sumber energi terbarukan (EBT) sebagai sumber energi listrik dengan peraturan yang di buat oleh Pemerintah akan efektif menghasilkan investasi di luar jaringan yang besar dimana Pemerintah menjamin para investor bahwa tarif RES tidak akan berubah selama periode pembayaran investasi mereka.Praktek internasional terhadap investor tidak dapat mengandalkan jaminan dan kekuatan yang diatur dalam jangka panjang terkait pembelian pada saat melakukan investasi di luar dari proyek RES of grid. Berdasarkan dukungan dari pemerintah maka perlu pendekatan regulasi alternatif untuk promosi investasi dan regulasi proyek of grid.

\subsection{Diskusi Grid Sebagai Energi Alternatif}

Kanada berhasil mengubah tarif investor tradisional RES (fees-in) untuk mendorong pembangunan RES di daerah terpencil negara menjamin pengembangan proyek listrik beroperasi bahwa listrik yang mereka hasilkan akan dijual. Penggunaan bahan bakar negara dapat melakukan pengelolaan dan juga mengatur ulang subsidi pasokan energi ke komoditas energi of grid.

\subsection{Biaya dan Tarif Energi yang Harus di Hindari}

Biaya operasional yang digunakan untuk mengoperasikan RES dan juga tarif untuk listrik dihasilkan dari RES ditentukan berdasarkan modal.Metode yang digunakan untuk biaya penjualan digunakan sebagai tarif alternatif adalah untuk menentukan tarif berdasarkan biaya yang dihindari yaitu berdasarkan biaya listrik yang tersedia sebelum pelaksanaan proyek RES di daerah terpencil.Manfaat penting dari pendekatan ini adalah bahwa RES tarif membutuhkan jaminan bahwa harga yang sudah ditentukan akan dipertahankan sampai durasi yang cukup untuk memastikan adanya pemulihan biaya investasi proyek.

Biaya energi perusahaan dapat dipertahankan melalui otoritas regulasi perusahaan untuk dapat menutupi peningkatan energi dapat menjaga keuntungan finansial yang di hasilkan dari investasi penghematan energi setidaknya dapat bertahan selama 5 tahun. Dengan demikian pemerintah dapat menjamin investor melakukan atau menerima tarif yang ada yang dihitung. Berdasarkan bahan bakar sebelumnya (lebih tinggi) dan perbedaaan antara biaya nyata mereka menggunakan 
langkah efisiensi energi untuk membantu investor membantu hambatan administratif proyek RES of grid di daerah terpencil memerlukan pendekatan alternatif tantangan dalam penentuan metode biaya yang dapat di hindari. Biaya investasi juga dapat berperan mengatasi biaya lingkungan di bawah undangundang sistem kelistrikan nasional salah satu sumber listrik adalah energi berbasil diesel biaya tambahan yang di gunakan akan mendekati biaya rata rata dalam setiap pengoperasiaanya (pembangkit listrik tenaga air dan gas) akan lebih murah dari biaya tambahan (solar) untuk memastikan kelangsungan investasi RES maka perlu memastikan biaya yang akan di hindari dan biaya yang akan disimpan.

Dalam pembangkit diesel ekonomi dihindari tergantung pada lokasi generator jam operasi dan juga peralatan yang digunakan dalam teknik konfigurasi sistem [26]. Biaya yang berbeda digerakkan oleh sistem yang berbeda maka memerlukan pendekatan khusus dalam menentukan tarif RES pertanyaan adalah apakah RES tarif ditentukan berdasarkan tarif yang dihindari untuk mencermikan biaya pembangkit diesel. Jika menyesuaikan tarif berdasarkan parameter investor terhadap ketidakpastian dan ketidakstabilan [27]. Pemerintah dapat menentukan atau menetapkan biaya yang dihindari untuk menghemat biaya tegangan jaringan biaya terakhir yang ditanggung adalah jarak yang memisahkan beban pusat atau daerah terpencil dari titik jaringan yang ada atau jaringan terpusat supaya dapat mempertimbangkan kebijakan elektrifikasi untuk wilayah Indonesia Bagian Timur.

\subsection{Kontrak Kinerja Energi}

Kontrak kerja menjadi solusi terhadap ketidakpastian dan ketidakstabilan yang dapat mempengaruhi proyek of grid demi tercapainya target penggunaan energi baru dan terbarukan. Kontrak kinerja energi bertujuan untuk pengaturan terhadap peningkatan efisiensi energi dan juga langkah hemat energi dan biaya hemat energi yang di hasilkan oleh ukuran tersebut [28]. Pengalaman-pengalaman internasional menunjukkan bahwa konstribusi yang diberikan oleh RES dapat menurunkan tingginya biaya pasokan energi di daerah terpencil. Dengan demikian kontrak kerja menjadi solusi untuk dapat pembiayaan proyek energi baru dan terbarukan di daerah terpencil. Kontrak kerja dapat di simpulkan antara penyedia dan penerima energi demi peningkatan efisisensi energi RES. dengan RES energi untuk penghematan keluaran listrik yang di hasilkan diharapkan dapat memproduksi listrik elektrik pertahun menjadi rata rata tahunan yang digunakan dalam sistem energi tertentu. Biaya solar di tentukan saat penyimpulan perjanjian layanan energi. 
Kesimpulan dari peraturan yang ada bahwa peraturan energi memberikan indikasi harga energi untuk penyesuaian harga.

\subsection{Transfer Energi dari Subsidi ke RES}

Biaya modal yang besar menjadi tantangan paling besar dalam melakukan investasi RES didaerah terpencil maka perlu subsidi dari pemerintah daerah ataupun pusat untuk menyokong dana demi tercapainya proyek RES di daerah terpencil sebagai contoh di negara Amerika Serikat, Alaska pemerintah menghibahkan dana ke pemerintah daerah untuk menciptakan energi baru terbarukan sebagi dukungan dan konstribusi terhadap penggunaan RES di wilayah khususnya di daerah terpencil [29]. Dana subsidi atau bantuan dari pemerintah(dana khusus) menjadi solusi demi memajukan listrik daerah terpencil.maka dengan demikian subsidi energi pembiayaan RES di luar jaringan bisa terwujud.

Sebagai contoh sebuah daerah di negara Rusia menerima subsidi melalui konpensasi lingkungan ekonomi yang ditanggung oleh pemasok dengan cara membebankan harga di bawah biaya reflektif hambatan terhadap efektifitas subsidi dari diesel ke RES di Indonesia tidak sesuai dengan biaya atau karakteristik ke uangan investasi res di indonesia.RES investasi adalah dapat di artikan sebagai biaya investasi realtif tinggi tetapi dengan biaya operasioanal yang rendah.ketidak pastian anggaran untuk investasi RES of grid sehingga tidak dapat di bangun investasi operasi dari tahun ke tahun.instalasi pembangkit diesel ditandai dengan operasi biaya yang sangat tinggi tetapi dengan modal yang rendah.

Daerah terpencil di Indonesia memerlukan kelayakan finansial untuk melakukan kelayakan dalam melakukan investasi RES.Namun dengan adanya keadaan menunggu secara struktural pendekatan struktur alternatif mungkin menjadi solusi terhadap kebijakan subsisdi: Undang-undang efisiensi energi menetapkan bahwa perencanaan pengadaan energi baru dan terbarukan dapat dibiayai dari anggaran pendapatan dan belanja negara atau pendapatan belanja daerah. Untuk membiayai energi regional demi meningkatkan langkah efisiensi energi dan juga promosi RES. Subsidi daerah tersebut dapat di alokasikan kembali ke wilayah dengan memperhitungkan efektifitas program efisiensi energi regional [30].

Selain itu subsidi dapat disediakan dalam kerangka pelaksanaan strategi pembangunan ekonomi dan sosial. Otoritas daerah juga dapat memutuskan untuk membuat yang berdedikasi menyediakan bantuan modal untuk proyek di luar jaringan.sebagai contoh Alaska renewable energi grand fund. Kemudian sumber pendapatan daerah untuk proyek pengadan 
RES bisa datang dari biaya yang dihindari dari proyek RES yaitu dengan mewajibkan investor dalam proyek ini (penyedia energi saat ini) untuk digunakan dan dibagikan ke bagian dana RES of grid dari penghematan biaya operasional energi.

\section{Kesimpulan}

Jurnal ini mengidentifikasi investasi of grid di Indonesia memiliki dukungan dari pemerintah untuk mengembangkan energi terbarukan RES of grid di daerah terpencil. Dukungan tersebut berupa adanya Peraturan Menteri ESDM Nomor 38 tahun 2016 tentang Percepatan Elektrifikasi di Pedesaan Belum Berkembang, Terpencil, Perbatasan dan Pulau Kecil Berpenduduk Melalui Pelaksanaan Usaha Penyediaan Tenaga Listrik Skala Kecil.

Permen ini memberikan kemudahan bagi Pemerintah Daerah untuk berkewenangan dalam memberikan kesempatan kepada badan usaha sebagai penyelenggara usaha penyediaan tenaga listrik terintegrasi untuk skala kecil.Selain itu dengan adanya dukungan pemerintah maka pengadaan dana dan investasi of grid di Indonesia dapat tercapai sebagaimana negara di eropa memiliki pengalaman bahwa keberhasilan RES dapat bergantung pada pembuatan mekanisme khususnya dalam pengembangan RES of grid.
Pengalaman internasional menunjukkan bahwa dengan menghindari biaya solar atau biaya tegangan jaringan dalam pengadaaan kontrak kerja energi pengalihan subsidi dari diesel ke dana khusus dapat berkonstribusi demi kelayakan finansial RES di daerah terpencil. Dengan biaya solar dalam jangka panjang yang dapat mempengaruhi keberlanjutan penyediaan energi terbarukan di daerah terpencil.

Dengan demikian manfaat biaya investasi di luar jaringan bergantung pada jaminan peraturan dan kontak yang sangat kuat antara Pemeritah Daerah dan Pemerintah Pusat untuk melindungi para penyedia investasi di daerah terpencil. Teknis kompleksitas proyek of grid hibrid RES pengeluaran modal yang tigggi dan logistik yang sulit menjadi tantangan di sektor tersebut. Kondisi ekonomi Indonesia saat ini sangat mendukung pembiayaan RES di daerah terpencil. Adanya dukungan investasi dan dukungan operasional dapat menjadi cara tersendiri dalam transisi dari diesel ke RES.

Investasi mekanisme pendukung dapat memberikan regulasi yang solid dalam memberikan investasi di luar jaringan di Indonesia. Pemerintah daerah berkomitmen untuk menghormati fondasi keuangan Pengadaan Proyek RES of grid dengan melakukan Perjanjian investasi dengan perusahaan energi. Jaminan tersebut sangat 
penting untuk di inplementasikan oleh investor baru yaitu perusahaan selain pemasok energi yang sudah ada. Pemerintah daerah perlu mengkoordinasikan kebijakan tengangan gridnya dengan penyebaran di luar jaringan nasional dan regional untuk dapat melindugi investor jaringan RES. Peraturan ini digunakan untuk melindungi jaminan sosial dan perlindungan lingkungan global.

\section{Daftar Pustaka}

[1] R. Wiser et al., "Wind Energy. In IPCC Special Report on Renewable Energy Sources and Climate Change," IPCC Spec. Rep. Renew. Energy Sources Clim. Chang. Mitig., 2011.

[2] M. Moner-Girona, "A new tailored scheme for the support of renewable energies in developing countries," Energy Policy, vol. 37, no. 5, pp. 20372041, 2009, doi: 10.1016/j.enpol.2008.11.024.

[3] K. N. Hasan, T. K. Saha, M. Eghbal, and D. Chattopadhyay, "Review of transmission schemes and case studies for renewable power integration into the remote grid," Renew. Sustain. Energy Rev., vol. 18, pp. 568-582, 2013, doi: 10.1016/j.rser.2012.10.045.

[4] S. C. Bhattacharyya, "Financing energy access and off-grid electrification: A review of status, options and challenges," Renew. Sustain. Energy Rev., vol. 20, pp. 462-472, 2013, doi: 10.1016/j.rser.2012.12.008.

[5] Y. Tan, L. Meegahapola, and K. M. Muttaqi, "A review of technical challenges in planning and operation of remote area power supply systems," Renew. Sustain. Energy Rev., vol. 38, pp. 876-889, 2014, doi: 10.1016/j.rser.2014.07.034.

[6] D. R. Thiam, "An energy pricing scheme for the diffusion of decentralized renewable technology investment in developing countries," Energy Policy, vol. 39, no. 7, pp. 42844297, 2011, doi: 10.1016/j. enpol.2011.04.046.

[7] M. F. Gómez and S. Silveira, "Delivering off-grid electricity systems in the Brazilian Amazon," Energy Sustain. Dev., vol. 16, no. 2, pp. 155167, 2012, doi: 10.1016/j.esd.2012.01.007.

[8] P. R. Bhattarai and S. Thompson, "Optimizing an off-grid electrical system in Brochet, Manitoba, Canada," Renew. Sustain. Energy Rev., vol. 53, pp. 709-719, 2016, doi: 10.1016/j.rser.2015.09.001.

[9] T. M. Weis, A. Ilinca, and J. P. Pinard, 
“Stakeholders' perspectives on barriers to remote wind-diesel power plants in Canada," Energy Policy, vol. 36, no. 5, pp. 1611-1621, 2008, doi: 10.1016/j.enpol.2008.01.004.

[10] S. Thompson and B. Duggirala, "The feasibility of renewable energies at an off-grid community in Canada," Renew. Sustain. Energy Rev., vol. 13, no. 9, pp. 2740-2745, 2009, doi: 10.1016/j.rser.2009.06.027.

[11] T. M. Weis and A. Ilinca, "Assessing the potential for a wind power incentive for remote villages in Canada," Energy Policy, vol. 38, no. 10, pp. 5504-5511, 2010 , doi: 10.1016/j.enpol.2010.04.039.

[12] A. K. Akella, M. P. Sharma, and R. P. Saini, "Optimum utilization of renewable energy sources in a remote area," Renew. Sustain. Energy Rev., vol. 11, no. 5, pp. 894-908, 2007, doi: 10.1016/j.rser.2005.06.006.

[13] M. R. Nouni, S. C. Mullick, and T. C. Kandpal, "Providing electricity access to remote areas in India: An approach towards identifying potential areas for decentralized electricity supply," Renew. Sustain. Energy Rev., vol. 12, no. 5, pp. 1187-1220, 2008, doi: 10.1016/j.rser.2007.01.008.
[14] B. Mainali and S. Silveira, "Renewable energy markets in rural electrification: Country case Nepal," Energy Sustain. Dev., vol. 16, no. 2, pp. 168-178, 2012, doi: 10.1016/j.esd.2012.03.001.

[16] S. Mahapatra and S. Dasappa, "Rural electrification: Optimising the choice between decentralised renewable energy sources and grid extension," Energy Sustain. Dev., vol. 16, no. 2, pp. 146-154, 2012 , doi: 10.1016/j.esd.2012.01.006.

[17] S. Martin and J. Susanto, "Supplying power to remote villages in Lao PDR. The role of off-grid decentralised energy options1," Energy Sustain. Dev., vol. 19, no. 1, pp. 111-121, 2014, doi: 10.1016/j.esd.2013.12.012.

[19] C. Banet, "Tradable Green Certificates The influence of EU law on national support," no. September, 2011.

[20] D. U. Galetta, H. Hofmann, O. M. Puigpelat, and J. Ziller, "The General Principles of EU Administrative Procedural Law (Analysis for the EUP JURI Committee)," vol. 151, pp. 10$17,2015$.

[23] T. M. Weis and A. Ilinca, "The utility of energy storage to improve the economics of wind-diesel power plants in Canada," Renew. Energy, vol. 33, 
no. 7, pp. 1544-1557, 2008, doi:

10.1016/j.renene.2007.07.018.

[24] H. Ibrahim, R. Younès, A. Ilinca, M. Dimitrova, and J. Perron, "Study and design of a hybrid wind-dieselcompressed air energy storage system for remote areas," Appl. Energy, vol. 87, no. 5, pp. 1749-1762, 2010, doi: 10.1016/j.apenergy.2009.10.017.

[25] "Indonesia Electricity Law No 30 Year 2009," 2009.

[26] M. Arriaga, C. A. Canizares, and M. Kazerani, "Renewable energy alternatives for remote communities in Northern Ontario, Canada," IEEE Trans. Sustain. Energy, vol. 4, no. 3, pp. 661-670, 2013, doi: 10.1109/TSTE.2012.2234154.

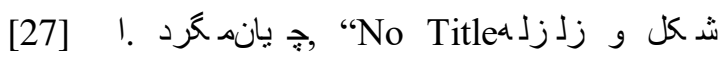

1369.

[28] European Commission, "Directive 2012/27/EU of The European Parliament and of The Council of 25 October 2012 on energy efficiency, amending Directives 2009/125/EC and 2010/30/EU and repealing Directives 2004/8/EC and 2006/32/EC," Off. J. Eur. Union, no. October 2012, pp. 156, 2012.

[29] K. Ardani, D. Hillman, and S. Busche, "Financing Opportunities for Renewable Energy Development in Alaska," p. Medium: ED; Size: 43 pp., 2013, [Online]. Available: http://www.osti.gov/bridge/servlets/pur 1/1078070/.

[30] K. ESDM, "Permen ESDM No. 39 Thn 2017.pdf." 2017. 